\title{
A small area analysis estimating the prevalence of addiction to opioids in Barcelona, 1993
}

\author{
M Teresa Brugal, Antònia Domingo-Salvany, Andrew Maguire, Joan A Caylà, \\ Joan R Villalbí, Richard Hartnoll
}

\begin{abstract}
Study objective-To determine the distribution of opioid use prevalence in small areas and its relation with socioeconomic indicators.

Design-Capture-recapture was applied using data from the Barcelona Drug Information System for 1993 (treatment demands, hospital emergency room visits, deaths from heroin acute adverse reaction and pre-trial prison admissions). To avoid dependence between sources, a log-linear regression model with interactions was fitted. For small neighbourhoods, where capture-recapture estimates were not obtainable, the Heroin Problem Index (HPI) was used to predict prevalence rates from a regression model. The correlation between estimated opioid use prevalence by neighbourhoods and their socioeconomic level was computed.

Main results-The city's estimated prevalence was 12.9 opioid addicts per 1000 inhabitants aged 15 to 44 years $(95 \%$ CI:10.1, 17.2), which represents 9176 persons. The highest rate was found in the inner city neighbourhood. Comparing rates obtained for each neighbourhood with their unemployment rates, a high correlation coefficient was obtained $(r=$ $0.80, \mathrm{p}<0.001$ ).

Conclusion-The main contribution of this study is that of combining capturerecapture with the HPI to produce small area prevalence estimates, which would not have been possible using only one method. Areas with higher socioeconomic status showed proportionally low addiction prevalences, but in depressed areas, prevalences varied widely.
\end{abstract}

(F Epidemiol Community Health 1999;53:488-494)

In recent years opioid consumption has been a cause of great concern because of its sociosanitary repercussions, in particular health problems (acquired immunodeficiency syndrome (AIDS), tuberculosis, hepatitis, etc) and the anti-social behaviour associated with it. Measuring the scope of this problem by gathering data regarding its spread and distribution is one of the most important steps towards evaluating and solving it.

The city of Barcelona has developed the Barcelona Drug Information System (SIDB), ${ }^{1}$ which in conjunction with the State Information System on Drug Abuse (SEIT), ${ }^{2}$ monitors various indirect indicators, such as drug treatment demands, deaths from acute adverse reaction to drugs, non-fatal drug related emergency room episodes, etc. Analysis of the system's data shows that in recent years the spread of drug use, especially intravenous drug use, has been considerable in Barcelona; drug related deaths have become one of the main causes of premature death. ${ }^{3}$ Intravenous drug users are the group at greatest risk for contracting $\operatorname{AIDS}^{4}$ and tuberculosis is the first AIDS defining disease. ${ }^{5}$ Similar patterns have been seen in several other cities and industrialised countries. $^{67}$

Studies measuring the prevalence of drug abuse done in other communities have proposed various methods, ${ }^{8-10}$ which can be classified as direct or indirect. There are basically two direct methods: identification of cases in existing registers, and population surveys. The most important indirect methods include: inference methods, nominative techniques, and the capture-recapture method with indirect indicators. None of these allow us to make accurate estimates of prevalence, and all have their limitations. ${ }^{11}{ }^{12}$ As often happens in social research, there is no ideal instrument of measurement. However, the capture-recapture method, using more than two sources, seems to be one of the most adequate. ${ }^{13-17}$

Previous studies in Barcelona show that drug addiction is unevenly distributed across the city. With a single indirect indicator used for analysis, this non-homogeneous distribution is highly related to socioeconomic indicators of poverty, ${ }^{18}{ }^{19}$ as well as to other contributing social factors, ${ }^{20}$ also recorded in other developed countries. ${ }^{21}$ Besides poverty itself, the crumbling of the traditional infrastructure that once provided a social safety net, the forced migration, a lack of facilities that promote social awareness among the young, and other factors such as unemployment, insufficient education, and a sense of solitude and distrust aggravated by the physical surroundings in which many people live, ${ }^{22}$ are all byproducts of this decomposition.

To ascertain the extent and territorial distribution of regular opioid consumption in Barcelona, we have used the capture-recapture method to estimate prevalence. Our aims were to determine the distribution according to small areas (districts and neighbourhoods), and to establish the degree of correlation between socioeconomic indicators and opioid consumption.

\section{Methods}

The main data source for the study was the SIDB $^{1}$ for the year 1993. It included treatment demands, hospital emergency room data, and 
Table 1 Patient distribution according to age and sex in indicator sources. (Barcelona 1993)

\begin{tabular}{|c|c|c|c|c|c|c|c|c|c|c|c|c|c|c|c|}
\hline Population age (y) & $\begin{array}{l}E^{\star} \text { yes } \\
T^{*} \text { yes } \\
P^{\star} \text { yes } \\
M^{*} \text { yes }\end{array}$ & $\begin{array}{l}E \text { yes } \\
T \text { yes } \\
P \text { yes } \\
M \text { no }\end{array}$ & $\begin{array}{l}E \text { yes } \\
T \text { yes } \\
P \text { no } \\
M \text { no }\end{array}$ & $\begin{array}{l}E \text { yes } \\
\text { T no } \\
\text { P no } \\
\text { М no }\end{array}$ & $\begin{array}{l}E \text { no } \\
T \text { yes } \\
P \text { yes } \\
M \text { yes }\end{array}$ & $\begin{array}{l}\text { E no } \\
T \text { yes } \\
P \text { no } \\
M \text { no }\end{array}$ & $\begin{array}{l}\text { Eno } \\
\text { T no } \\
P \text { yes } \\
M \text { no }\end{array}$ & $\begin{array}{l}\text { Eno } \\
\text { T no } \\
P \text { no } \\
M \text { yes }\end{array}$ & $\begin{array}{l}E \text { no } \\
T \text { yes } \\
P \text { yes } \\
M \text { no }\end{array}$ & $\begin{array}{l}E \text { yes } \\
T \text { no } \\
P \text { yes } \\
M \text { no }\end{array}$ & $\begin{array}{l}\text { Eno } \\
\text { T no } \\
P \text { yes } \\
M \text { yes }\end{array}$ & $\begin{array}{l}\text { E no } \\
\text { Tyes } \\
P \text { no } \\
M \text { yes }\end{array}$ & $\begin{array}{l}\text { E yes } \\
\text { T no } \\
P \text { no } \\
M \text { yes }\end{array}$ & $\begin{array}{l}\text { Eyes } \\
\text { Tno } \\
P \text { yes } \\
M \text { yes }\end{array}$ & $\begin{array}{l}\text { Eyes } \\
T \text { yes } \\
P \text { no } \\
M \text { yes }\end{array}$ \\
\hline Barcelona total & 0 & 19 & 157 & $771 \dagger$ & 0 & 841 & 298 & 83 & 37 & 68 & 2 & 16 & 10 & 1 & 7 \\
\hline Young men $(15-29)$ & 0 & 6 & 58 & 368 & 0 & 355 & 163 & 47 & 15 & 35 & 2 & 8 & 5 & 0 & 6 \\
\hline Young women (15-29) & 0 & 7 & 45 & 138 & 0 & 151 & 32 & 6 & 8 & 16 & 0 & 3 & 1 & 1 & 1 \\
\hline Older men (30-44) & 0 & 6 & 46 & 205 & 0 & 250 & 81 & 25 & 10 & 13 & 0 & 5 & 3 & 0 & 0 \\
\hline Older women (30-44) & 0 & 0 & 8 & 58 & 0 & 85 & 22 & 5 & 4 & 4 & 0 & 0 & 1 & 0 & 0 \\
\hline
\end{tabular}

${ }^{\star}$ E: total emergencies: 1033 patients. T: total treatment demands: 1077 patients. P: total prisons: 425 persons. M: total mortality by acute drug reaction: 119 deaths. †Age of one man and one woman not known from emergency room files. We assumed they were 15-44 years old, because it is the most frequently attended group.

registered deaths from acute adverse reaction to drugs. We also added an indicator from pretrial prison admissions in Barcelona.

Treatment admissions refer to everybody who requested treatment for opioid addiction during the first six months of 1993 at any of the drug treatment centres in the city, as well as those who began treatment at other Catalan centres. Only people listed as residents of Barcelona were considered. A case was defined as a person who had regularly used (daily or nearly so) any opioid substance during the 30 days before receiving treatment in any one of these centres.

Our emergency room source included all non-fatal episodes recorded in the first six months of 1993 in the five major hospitals in Barcelona, which according to a 1989 study, handled 95 per cent of the city's drug related cases. ${ }^{18}$ Any episode that resulted in a patient file recording current use of opioids was considered a case.

For mortality, we considered that death had resulted from opioid acute adverse reaction when a confirming necropsy performed at the Forensic Anatomy Institute and a coroner's report based on organic samples (blood and tissue) had determined the cause of death as an opioid overdose. Data on overdose deaths cover all 1993.

Legal data came from the pre-trial admissions of Barcelona's three prisons (men, women, and youth). Cases were selected from admissions during the last six months of 1993. Medical records of people who were registered as drug users on admission were reviewed to find out if opioids had been used on a daily or nearly daily basis, during the past 30 days.

After examining the reliability and internal coherence of the episodes for the chosen indicators and selecting persons aged 15 to 44 years old, we decided upon identifying elements that could be used to link registers. These were the first three letters of both last
KEY POINTS

- The main contribution of this study is the combining of analyses to estimate opioid addiction prevalence rates in small areas.

- The estimated prevalence rate for Barcelona was 12.9 opioid addicts per 1000 inhabitants aged from $15-44$ years.

- Rates were not distributed uniformly between small areas.

- Socioeconomic factors partially explained the heroin consumption. In neighbourhoods with high unemployment rates opioid prevalence rates varied widely.

- This type of research is of particular interest for resource allocation, management and policy making.

names, date of birth, and sex. An algorithm was designed to maximise the probability of unequivocal identification of a person associated with an episode. Its validity had been confirmed previously in 97 per cent of pairings, with sensitivity and specificity both greater than 95 per cent. ${ }^{23}$ With this method we rejected extremely unlikely linkages, the rest were reviewed visually.

Cases were paired according to the degree of overlap in the different sources (table 1). To avoid possible dependence between sources, a log-linear regression model with interactions was fitted. ${ }^{24}$ To fit the capture-recapture model with multiple sources we used the GLIM program. ${ }^{25}$ Models fitting the data well according to the deviance and the residuals were considered and Akaike's Information Criteria $(\mathrm{AIC})^{26}{ }^{27}$ applied to select one model. Likelihood based $95 \%$ confidence intervals were estimated using a GLIM macro based on the method proposed by Regal and Hook..$^{28}$

To minimise capture heterogeneity, we stratified by age, sex, and district of residence, constructing a model for each. For prevalence

Table 2 Distribution of number of addicts estimated from emergencies, treatment, and prison; rates according to sex and age group. (Barcelona 1993)

\begin{tabular}{|c|c|c|c|c|c|c|c|c|}
\hline Population age $(y)$ & $\begin{array}{l}\text { Indicator } \\
\text { sources }\end{array}$ & $\begin{array}{l}\text { Number } \\
\text { found }\end{array}$ & Interactions & Deviance & $\begin{array}{l}\text { Degrees } \\
\text { of } \\
\text { freedom }\end{array}$ & $\begin{array}{l}\text { Missing cases } \\
(95 \% \text { CI })\end{array}$ & $\begin{array}{l}\text { Estimated total cases } \\
(95 \% \mathrm{CI})\end{array}$ & $\begin{array}{l}\text { Prevalence rates per } \\
1000 \text { inhabitants } \\
(95 \% \mathrm{CI})\end{array}$ \\
\hline Barcelona total (15-44) & ETP* $^{\star}$ & $2227^{\star}$ & E.T + E.P & 0.945 & 1 & $1,9995)$ & $9176(7188,12222)$ & $, 17.2)$ \\
\hline Total men (15-44) & ETP & 1641 & E.T + E.P & 0.65 & 1 & $6081(4069,9475)$ & $7722(5710,11116)$ & $21.9(16.2,31.5)$ \\
\hline Total women $(15-44)$ & ETP & 586 & E.P & 0.60 & 2 & $897(669,1209)$ & $1483(1255,1795)$ & $4.2(3.5,5.0)$ \\
\hline Young men $(15-29)$ & ETP & 1021 & E.T + E.P & 0.00 & 1 & $3993(2402,7161)$ & $5014(3423,8182)$ & $25.9(17.7,42.2)$ \\
\hline Young women (15-29) & ETP & 403 & E.P & 0.74 & 2 & $475(337,669)$ & $878(740,1072)$ & $4.7(3.9,5.7)$ \\
\hline Older men $(30-44)$ & ETP & 619 & E.T + E.P & 1.84 & 1 & $2066(1105,4303)$ & $2685(1724,4922)$ & $16.9(10.8,30.9)$ \\
\hline Older women $(30-44)$ & ETP & 182 & & 1.78 & 3 & $546(314,996)$ & $728(496,1178)$ & $4.3(2.9,6.9)$ \\
\hline
\end{tabular}

E: opioid emergency room cases Barcelona, Jan-June 1993. Total emergencies: 1033 patients. T: opioid treatment demands Barcelona, Jan-June 1993. Total treatment demands: 1077 patients. P: opioid consumers admitted to prison Barcelona July-Dec 1993. Total prisons: 425 persons. ${ }^{\star}$ Age of one man and one woman not known from emergency room files. We assumed they were 15-44 years old, because it is the most frequently attended group. 
Table 3 Distribution of number of addicts estimated from emergencies, treatment demands, prison and mortality registers; rates according to sex and age group. (Barcelona 1993)

\begin{tabular}{|c|c|c|c|c|c|c|c|c|}
\hline Population age (y) & $\begin{array}{l}\text { Indicator } \\
\text { sources }\end{array}$ & $\begin{array}{l}\text { Number } \\
\text { found }\end{array}$ & Interactions & Deviance & $\begin{array}{l}\text { Degrees } \\
\text { of } \\
\text { freedom }\end{array}$ & $\begin{array}{l}\text { Missing cases } \\
(95 \% \mathrm{CI})\end{array}$ & $\begin{array}{l}\text { Estimated total cases } \\
(95 \% \mathrm{CI})\end{array}$ & $\begin{array}{l}\text { Prevalence rates per } \\
1000 \text { inhabitants } \\
(95 \% \text { CI })\end{array}$ \\
\hline Barcelona total $(15-44)$ & METP* & $2310^{\star}$ & M.T+M.E+E.T+E.P & 5.79 & 6 & $7572(5484,10698)$ & $9882(7794,13008)$ & $13.9(11.0,18.3)$ \\
\hline Total men (15-44) & METP & 1713 & M.T+E.T+E.P & 7.54 & 7 & $6074(4299,8847)$ & $7787(6012,10560)$ & $22.1(17.0,29.9)$ \\
\hline Total women (15-44) & METP & 597 & E.P & 3.90 & 9 & $888(669,1185)$ & $1485(1266,1782)$ & $4.2(3.5,5.0)$ \\
\hline Young men $(15-29)$ & METP & 1068 & M.T+M.E+E.T+E.P & 6.16 & 6 & $4648(2852,8016)$ & $5716(3920,9084)$ & $29.5(20.2,48.6)$ \\
\hline Young women (15-29) & METP & 409 & E.P & 4.54 & 9 & $462(331,644)$ & $871(740,1053)$ & $4.7(4.0,5.6)$ \\
\hline Older men (30-44) & METP & 644 & E.T+E.P & 6.72 & 8 & $1985(1209,3439)$ & $2629(1853,4083)$ & $16.5(11.6,25.7)$ \\
\hline Older women $(30-44)$ & METP & 187 & - & 4.27 & 10 & $563(328,1009)$ & $750(515,1196)$ & $4.4(3.0,7.1)$ \\
\hline
\end{tabular}

E: opioid emergency room cases Barcelona, Jan-June 1993. Total emergencies: 1033 patients. T: opioid treatment demands Barcelona, Jan-June 1993. Total treatment demands: 1077 patients. P: opioid consumers admitted to prison Barcelona, July-Dec 1993. Total prisons: 425 persons. M: mortality by acute drug reaction Barcelona, Jan-Dec 1993. Total mortality by acute drug reaction: 119 deaths. ${ }^{\star}$ Age of one man and one woman not known from emergency room files. We assumed they were 15-44 years old, because it is the most frequently attended group.

estimation in neighbourhoods, the smallest territorial division within the district, there were too few subjects to apply this method, so two procedures were combined. Firstly, for each of the neighbourhoods the Heroin Problem Index $(\mathrm{HPI})^{29}$ was calculated. This was achieved by ranking all neighbourhoods, from low to high, for each of the components of the index (specific neighbourhood rates for four capture-recapture sources: emergency rooms, treatment admissions, mortality and pre-trial admissions) and assigning a rank score accordingly. The component rank scores were then summed by neighbourhood, giving the HPI for each of them. Then, for those neighbourhoods for which we had high enough numbers (did not have any empty cell, except the unknown one) to compute capture-recapture, neighbourhood prevalence was estimated. Finally, using these neighbourhood prevalence estimates as anchor points, we fitted a regression model relating prevalence rates to HPI. Hence, the remaining neighbourhood rates were taken to be the fitted regression values for prevalence dependent on HPI. For clarity of expression, we shall refer to the rates estimated from the capture-recapture model as being "estimated rates" and those derived from the regression model (RM) as being "RM fitted rates".

Prevalence rates were estimated using the resident population, between the ages of 15 and 44 , for the year 1991. Unemployment and illiteracy rates for this age range, obtained from the 1991 census survey interviews, ${ }^{30}$ were the socioeconomic level indicators used. Correlation between estimated prevalence by neighbourhoods and their socioeconomic level was carried out by means of Spearman correlation coefficient statistics.

\section{Results}

Our sample consisted of 2310 people, 1077 of whom came from the treatment demand indicator $(\mathrm{T}) ; 1033$ from the emergency room indicator (ER); 425 from pre-trial prison admissions (P); and 119 from the mortality register $(\mathrm{M})$. Table 1 shows the frequency distributions by source and the degree of overlap among registers.

Samples were compared two by two using the formula derived by Chapman. ${ }^{31}$ The estimates for the whole group ranged between 5000 and 8000 people, depending on the sources analysed. The estimates from two loglinear Poisson regression models for every age and gender strata were compared, one based on three sources (ER;T;P) (table 2) and the other with a fourth additional source (M) (table 3 ). For both models, interactions between the sources were modelled so as to account for any dependence between samples. Both resulted in similar estimates, however those from the "four-source" model were less stable, as there were empty cells in different strata.

As table 2 shows, the city's estimated prevalence rate was 12.9 opioid addicts per 1000 inhabitants between the ages of 15 and 44 years (95\% CI 10.1, 17.2), which is derived from the estimated total of 9176 persons in this age group addicted to opioids in Barcelona. Rates were not distributed uniformly, either between sexes or age groups. Men were the most affected, particularly young men. Adding up the estimates derived separately for each sex and for different age groups, we see that the result is similar to the city's overall estimate.

Patients included in the indicator sources were only 24.3 per cent of the total estimated. A similar figure was obtained for men alone (21.3

Table 4 Distribution of estimated number of addicts and rates by residential district. (Barcelona 1993)

\begin{tabular}{|c|c|c|c|c|c|c|c|c|}
\hline Population & $\begin{array}{l}\text { Indicator } \\
\text { sources }\end{array}$ & $\begin{array}{l}\text { Number } \\
\text { found }\end{array}$ & Interactions & Deviance & $\begin{array}{l}\text { Degrees } \\
\text { of } \\
\text { freedom }\end{array}$ & $\begin{array}{l}\text { Missing cases } \\
(95 \% \text { CI })\end{array}$ & $\begin{array}{l}\text { Estimated total cases } \\
(95 \% \mathrm{CI})\end{array}$ & $\begin{array}{l}\text { Prevalence rates per } \\
1000 \text { inhabitants } \\
(95 \% \mathrm{CI})\end{array}$ \\
\hline Total & ETP & 2227 & E.T + E.P & 0.945 & 1 & $6949(4961,9995)$ & $9176(7188,12222)$ & $12.9(10.1,17.2)$ \\
\hline Ciutat Vella & ETP & 514 & - & 4.97 & 3 & $665(504,876)$ & $1179(1018,1390)$ & $35.4(30.5,41.7)$ \\
\hline Eixample & ETP & 207 & - & 2.27 & 3 & $372(232,605)$ & $579(439,812)$ & $5.2(3.9,7.2)$ \\
\hline Sants-Montjuïc & ETP & 258 & - & 1.92 & 3 & $400(268,603)$ & $658(526,861)$ & $8.5(6.8,11.2)$ \\
\hline Les Corts-Pedralbes & ETP & 63 & - & 2.89 & 3 & $106(44,269)$ & $169(107,332)$ & $4.1(2.6,8.0)$ \\
\hline Sarrià-Sant Gervasi & ETP & 96 & - & 6.69 & 3 & $233(109,540)$ & $329(205,636)$ & $5.0(3.1,9.6)$ \\
\hline Gràcia-Vallcarca & ETP & 115 & - & 2.12 & 3 & $175(92,338)$ & $290(207,453)$ & $5.4(3.8,8.4)$ \\
\hline Horta-Guinardó & ETP & 219 & - & 1.25 & 3 & $374(238,593)$ & $593(457,812)$ & $7.2(5.5,9.8)$ \\
\hline Nou Barris & ETP & 296 & T.P & 0.98 & 2 & $681(423,1132)$ & $977(719,1428)$ & $11.7(8.7,17.2)$ \\
\hline Sant Andreu & ETP & 177 & T.P & 2.52 & 2 & $256(143,466)$ & $433(320,643)$ & $6.6(4.9,9.8)$ \\
\hline Sant Martí & ETP & 232 & - & 0.93 & 3 & $406(261,637)$ & $638(493,869)$ & $6.8(5.2,9.2)$ \\
\hline
\end{tabular}

E: opioid emergency room cases Barcelona, Jan-June 1993. T: opioid treatment demands Barcelona, Jan-June 1993. P: opioid consumers admitted to prison Barcelona, July-Dec 1993. 


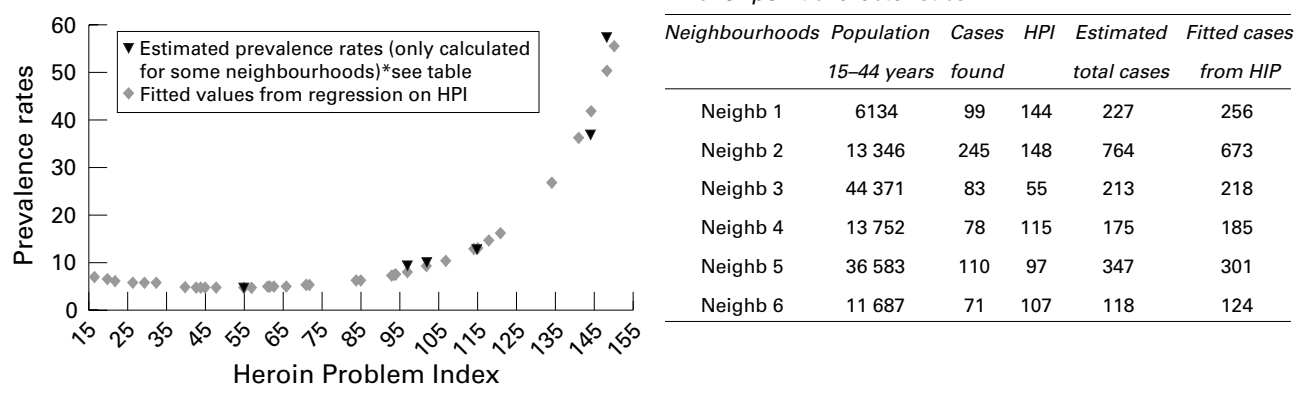

Figure 1 Heroin Problem Index and opioid addiction prevalence rates obtained with regression model by neighbourhood. Anchor point characteristics from some neighbourhoods. Barcelona 1993.

per cent). In the case of women the source indicators found 39.5 per cent of the total. By age groups, no differences were seen, with the figure remaining around 21 per cent, except for young women, where it was 45.9 per cent. Emergency room files report 11.3 per cent of the total cases; treatment initiation, 11.7 per cent; and pre-trial prison admissions, only 4.6 per cent.

Applying log-linear models to residence area (table 4), we found the highest prevalence rate in Ciutat Vella, the inner city, where the rate was three times as high as the city as a whole. Next came Nou Barris with a rate more than two thirds lower. However, totalling the estimates for each of the areas did not equal the city total. This fact is probably because of small numbers of subjects in each area not allowing dependence between sources to be introduced in all of them.

When relating estimated prevalence rates for the six neighbourhoods used as anchor points with their HPI, the following RM was obtained: Neighbourhood prevalence rate $=$ $\mathrm{e}\left(2.2552-0.02586 \times \mathrm{HPI}_{\mathrm{i}}+0.00025079 \times\right.$ $\mathrm{HPI}_{\mathrm{i}}^{2}$ ).

This function fitted the data well $\left(r^{2}=98.6\right)$; simpler functions either did not give good fit or produced unrealistic shapes. Applying this curve we were able to estimate the prevalence rate for the remaining neighbourhoods (fig 1).

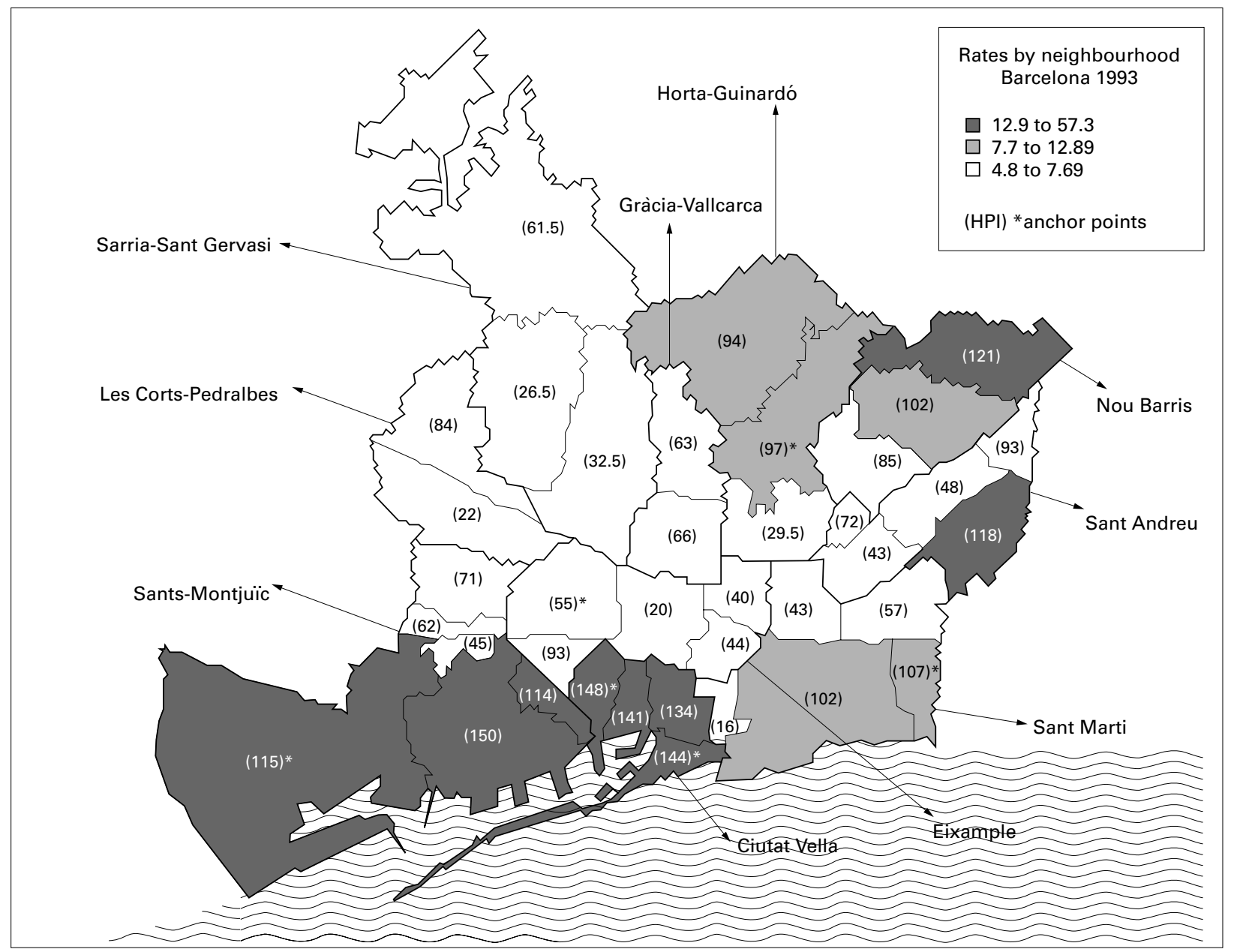

Figure 2 Distribution of fitted prevalence rates for opioid addiction by neighbourhood obtained from regression model. HPI values for each neighbourhood and anchor points. Barcelona 1993. 


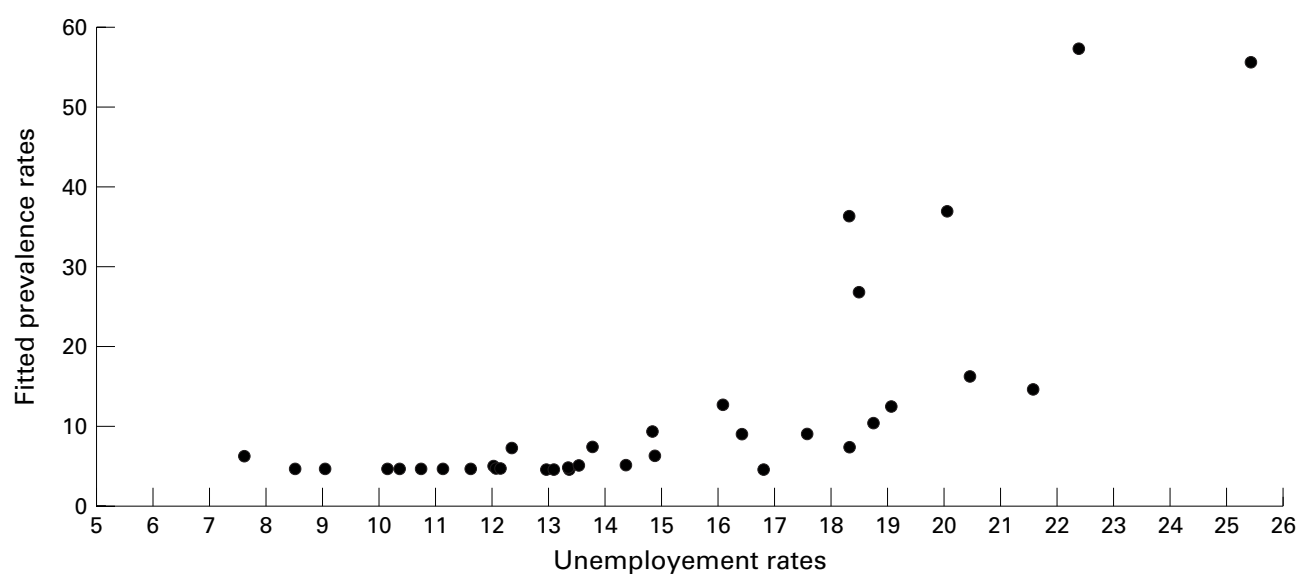

Figure 3 Plot of fitted prevalence rates of opioid addiction by unemployment rates, Barcelona 1993.

The curve resulting from the above formula fitted well to the intermediate anchor points. But at the upper extreme (maximum rates), RM underestimated the value found with the capture-recapture methods, while in the lower end the curve had a tendency to rise (fig 1). Therefore, in the lower HPI distribution we assumed that there were no differences between neighbourhoods, and all of them were subsequently assigned an estimated prevalence rate of 4.9 per 1000 inhabitants, the lowest anchor point calculated by the capturerecapture method. These RM fitted rates show a level of heterogeneity not seen in the distribution by district (fig 2), showing nine neighbourhoods with rates greater than the average for all Barcelona.

Comparing prevalence rates obtained using the above procedure with the unemployment rates for people aged from 15-44 years in each neighbourhood (fig 3), we observed a high correlation $(r=0.80, \mathrm{n}=38, \mathrm{p}<0.0001)$. A similar figure was obtained when unemployment rates were substituted by illiteracy for the same age group.

\section{Discussion}

We believe that one of this study's main contributions is the combining of analyses to estimate prevalences in small areas. To estimate the population in a small stratum where capture-recapture cannot be applied is one of the most important challenges in this field. ${ }^{32}$ Combining the capture-recapture method with HPI, a methodology previously unused, allowed us to make estimates that would not have been possible by using only one method. This technique gave us a numeric estimation, an advantage over the HPI, which affords only a ranking order. With this estimation, the difference between numbers of addicts per neighbourhood may be appreciated. In public health, knowing the approximate number of patients affected by disease is very important in designating resources for planning, intervention and evaluation. Here lies the importance of this study, which demonstrates how such prevalence rates can be estimated when no other method is available.

Before discussing the results, study limitations, such as the lack of specificity of some indicators, must be considered. In relation to disease definition, in the emergency room source the patient himself declared whether or not he had consumed an opioid. A previous study revealed that 92 per cent of these patients tested positive for the substance they claimed to have taken..$^{33}$ In treatment and prison we can assume the specificity of case definition because a physician had carried out a detailed examination. Another limitation is the violation of the assumption of capture homogeneity. As some authors have pointed out, ${ }^{164}$ we may have fallen short in the capture of habitual consumers from the upper social classes as well as those whose opioid use is less problematic. Patients who attended emergency rooms or treatment had an average length of consumption of seven years ${ }^{135}$; therefore, short-term consumers are less likely to be counted among our sources. Although both the emergency room and prison sources are likely to be more sensitive to these cases the study may underestimate the real prevalence, and may reflect more the prevalence of problematic long term opioid use.

Although with log-linear regression models we try to control source dependence by including all significant interactions into the model, small capture samples may preclude the inclusion of interaction terms. This was the case for district estimates where not including interaction terms controlling for positive dependence led to an underestimate for most of them, reflected in the discrepancy between the estimate for Barcelona and the sum of district estimates. However, to force interactions into the model may lead to a lack of precision in the estimated interaction coefficient, and in turn this affects the constant value from which the estimate for the unknown cell is derived. Attempting to build a saturated model, as Hook and Regal propose, ${ }^{27}$ always produces very wide confidence intervals ${ }^{36}$ and it may even be impossible to achieve a stable model. A measure to eliminate temporal dependence between sources was to collect data at different time periods, for example, prison and treatment.

When calculating prevalence rates as " $\mathrm{RM}$ fitted" for those neighbourhoods with small numbers, we have another limitation as all RM 
fitted rates are based on six anchor points with their estimated prevalence. However, as those anchor points covered a large range of HPI scores, interpolation of data was feasible. Nevertheless neighbourhood estimates, as district estimates, are underestimates reflecting the lack of inclusion of interaction terms in the anchor points estimated rates.

We applied HPI as it was first described by its authors, thus applying the same weights to all indirect indicators. We have explored principal components analysis to apply different weights to different indicators. The results obtained after applying them produced a very similar rank order for neighbourhoods, which did not change previous results. After applying HPI in this study we can suggest that HPI is more accurate when more valid indirect indicators are used and can achieve more precise results if more areas are involved. If HPI is used to estimate rates through regression techniques, what is important is to have enough anchor points covering a wide range of HPI.

Of all estimation techniques for prevalence in hidden populations, we believe, as do other authors, ${ }^{26}{ }^{37}$ that this is the most cost effective method, offering the most reliable estimate of the real prevalence. Other techniques, such as population surveys or those used in groups of specific populations, are expensive and less valid, as those surveyed may hide the presence of the phenomenon. The other direct method, case identification, involves costly active surveillance and the possibility of counting some cases more than once. Nominative techniques, whether by the applied sample technique or by names reported, are limited by the representativeness of the studied population.

If we compare our results with those from Barcelona, $1989,{ }^{16}$ we see that the prevalence is 40 per cent higher in 1993. However, this is probably not attributable to a rise in the prevalence of opioid addicts during those four years. All available indicators ${ }^{38}$ point to a stabilisation of the problem. The difference probably comes from the use of the prison source, which gave access to a subgroup of addicts not taken into account in 1989. Its inclusion allowed us to estimate the real situation with more precision, as consumers reached through prison probably constitute a different subpopulation from those reached through treatment centres or emergency rooms. Similar results have been found by other authors. ${ }^{39}$

Among women we barely saw any differences between the age groups 15-29 years and 30-44 years in the overall prevalence estimates. This contrasts with what has been observed in other studies. $^{4041}$ Our source indicators, however, picked up 45.9 per cent of the city's overall estimate for younger women, while only catching 25 per cent of the older, indicating that the younger may be more visible. For men, 65 per cent fell among the younger group; this figure is smaller than that observed in 1989, thus the proportion of older men has increased. For men these proportions are similar to those usually observed with indirect indicators alone. ${ }^{41}$ Such indicators have been our capture sources.
Thanks to the small area analysis, we were able to pinpoint where opioid consumption is most rampant and destructive. Viewing these small areas in relation to socioeconomic indicators, we find that all the small areas with higher socioeconomic status show proportionally low addiction prevalences. On the other hand, among the most depressed areas, prevalences vary widely. Perhaps the factor explaining this variability lies among "group contextual variables". ${ }^{42}$ The interaction among people in the community affects the transmission of beliefs, behaviours and values. This phenomenon, described in the study of contagious diseases, may be applicable to health related behaviours where social learning plays an important part, as in the case of opioid addiction. Perhaps for addiction the behaviour of the individual person is not independent of that of others, and some kind of synergism occurs in the group. This may explain why in neighbourhoods with similarly high unemployment rate prevalences vary considerably, and these differences have been widening over recent years. ${ }^{43}$

Another explanation could be that while poverty and deprivation are major risk factors for drug use in a community, a firm social structure may act as a buffer. Although difficult to measure, this concept may be represented by what has been called social capital, ${ }^{44}$ that is, the organisational capacity of a society to act as a self regulator. In fact, some authors have reported that informal social control and cohesion are good indicators to predict lower rates of violence. ${ }^{45}$

A third possible explanation is the so called social disintegration, ${ }^{46}$ by which a whole area finds itself on the margin of society because a small number of people within that area have undergone a process of margination. This leads to the development of the phenomenon known as "inner city". We think that all three of these explanations are interrelated, making it impossible to determine which causes another.

This type of research is of particular interest for resource allocation, management and policy making. Along this line, we point out that addicts from prison may not be included in health services registers, leading to the observation that this group should be taken into account when resources are distributed. Small area analysis of addiction prevalence helps us to set such priorities in the field of prevention as well as in the management of this chronic illness.

The authors thank the data collection team: P Albertín, D Grauges, A Queralt, I Ricart, and the prison physicians for providing data and to Dave Macfarlane who assisted in data management.

Funding: this work was partially supported by a grant from FIS (Fondo de Investigaciones Sanitarias) 93/354. Additional support was received from CIRIT (Comissió Interdepartamental de Recerca i Innovació Tecnològica) 95/SGR00434.

Conflicts of interest: none.

1 Brugal MT, Graugés D, Queralt A, et al. Sistema d'Informació de Drogodependencies de Barcelona (SIDB). Informe 1994 Darcelona (SIDB). Informe 1994 Barcelona. Barce

2 Delegación del Gobierno para el Plan Nacional Sobre Drogas. Sistema Estatal de Información sobre Toxicomanias gas. Sistema Estatal de Información sobre Toxicomanias
(SEIT). Informe año 1994. Madrid: Ministerio de Sanidad y (SEIT). Informe año
Consumo, 1995. 
3 Montellà N, Borrell C, Brugal MT, et al. Evolución de la mortalidad en los jóvenes de la ciudad de Barcelona: 19831993. Med Clin (Barc) 1997;108:241-7.

4 Caylà JA, Jansà JM, Iglesias B, et al. Epidemiología del síndrome de inmunodeficiencia adquirida en Barcelona (1981-1991) (I). Estudio descriptivo y de tendencias temporales. Med Clin (Barc) 1993;101:286-93.

5 Caylà JA, Marco A, Bedoya A, et al. Differential caracteristics of AIDS patients with a history of imprisonment. Int $\mathcal{f}$ Epidemiol 1995;24:1188-96.

6 de la Fuente 1, Barrio G, et al. The impact of drug related death on mortality among young adults in Madrid. $A m \mathcal{F}$ Public Health 1995;85:102-4.

7 European Centre for Epidemiological Monitoring of AIDS HIVIAIDS Surveillance in Europe. Paris: Quarterly Report no 50, June 1996

8 Korf DJ, Reijineved SA, Toet J. Estimating the number of heroin users: A review of methods and empirical findings from The Netherlands. Int $\mathcal{F}$ Addict 1994;29:1393-417.

9 Hartnoll R. Overview of existing research methods. In: Garretsen $\mathrm{H}$, van de Goor L, Kaplan. Illegal drug use: research retsen $\mathrm{H}$, van de Goor L, Kaplan. Illegal drug use: research methods

10 Wickens TD. Quantitative methods for estimating the size of a drug-using population. F Drug Issues 1993;23:185-216.

1 Hartnoll R, Lewis R, Mitcheson M. Estimating the prevalence of opioid dependence. Lancet 1985;i:203-5.

12 Larson A, Bammer G. Why? Who? How? Estimating numbers of illicit drug users: lessons from a case study from the Australian Capital. Aust N Z F Public Health 1996;20:4939.

13 McCarty DJ, Tull ES, Moy CS, et al. Ascertainment corrected rates: Aplications of capture-recapture methods. Int $\mathcal{F}$ Epidemiol 1993;22:559-65.

14 Abeni DD, Bracanto G, Perucci CA. Capture-recapture to estimate the size of population with human immunodeficiency virus type 1 infection. Epidemiology 1994;5:41014.

15 Bloor M, Leyland A, Barnard M, et al. Estimating hidden populations: a new method of calculating the prevalence of drug-injecting and non-injecting
$B r \mathcal{F}$ Addict 1991;86:1477-83.

16 Domingo-Salvany A, Hartnoll RL, Maguire A, et al. Use of capture-recapture to estimate the prevalence of opiate addiction in Barcelona, Spain, 1989. Am F Epidemiol 1995 141:567-74.

17 Fischer M, Leyland A, Cormack R, et al. Estimating the population prevalence of injection drug use and infection with human immunodeficiency virus among injection drug users in Glasgow, Scotland. Am F Epidemiol 1993;138:17081.

18 Domingo-Salvany A, Hartnoll R, Antó JM. Opiate and cocaine consumers attending Barcelona emergency rooms: a one year survey (1989). Addiction 1993;88:1247-56.

19 Borrell C, Arias A. Socioeconomic factors and mortality in urban settings: the case of Barcelona (Spain). $\mathcal{f}$ Epidemiol Community Health 1995;49:460-2.

20 Torralba L1, Brugal MT, Villalbí JR, et al. Mortality due to acute adverse drug reactions: opiates and cocaine in Barceacute adverse drug reactions: opiates and coc

21 Wallace R. Urban desertification, public health and public order planned shrinkage, violence death, substance abuse and AIDS in the Bronx. Soc Sci Med 1990;31:801-13.

22 Wilkinson J, Lawes G, Unell L, et al. Problematic drug use and social deprivation. Public Health 1987;101:165-8

23 Ortí RM, McFarlane D, Domingo-Salvany A. Obtención de una cohorte de adictos a opiáceos a partir de la conexión de registros confidenciales. Gac Sanit 1994;8:229-38.

24 Bishop YMM, Fienberg SE, Holland PW. Discrete multivariate analysis: theory and practice. Cambridge, MA: MIT Press, 1995.

25 Francis B, Green M, Payne C, eds. The GLIM system: generalized linear interactive modeling. Oxford: Clarendon Press, 1993. ISBN 0198522312
26 Hook EB, Regal RR. Capture-recapture methods in epidemiology: methods and limitations. Epidemiol Rev 1995; 17:243-64.

27 Hook EB, Regal RR. Validity of methods for model selection, weighting for model uncertainty, and small sample adjustment in capture-recapture estimation. Am $\mathcal{F}$ Epidemiol 1997;145:1138-44.

28 Regal RR, Hook EB. Goodness-of-fit based confidence intervals for estimates of size of closed population. Stat Med 1984;3:287-91.

29 Person Ph, Retka RL, Woodward JA. Towards a heroin problem index. An analytical model for drug abuse indicators. Rockville: US Department of Health, Education and Welfare, Public Health Service, National Institute on Drug Abuse, 1978.

30 Padró d'habitants de la Ciutat de Barcelona 1991. Barcelona: Servei d'Estadística Municipal, Ajuntament de Barcelona, 1992.

31 Chapman DG. Inverse, multiple, and sequential sample censuses. Biometrics 1952;8:286-306.

32 Neugebauer R, Wittes J. Annotation: Voluntary and involuntary capture-recapture samples. Problems in the estimation of hidden and elusive population. Am f Public Health 1994;84:1068-9.

33 Perez K, Domingo A, de la Torre R, Hartnoll R. Validación de la información sobre el uso de drogas notificada por parte de consumidores de opioides/cocaína en un servicio de urgencias. [Abstract]. Gac Sanit 1994;8:33.

34 Mastro TD, Kitayaporn D, Weniger BG, et al. Estimating the number of HIV-Infected injection drug users in Bangkok: A capture-recapture method. Am f Public Health 1994;84:1094-9.

35 Perez K, Domingo-Salvany A, Hartnoll R. Prevalencia de consumo de drogas ilegales en un servicio de urgencias. [Letter]. Med Clin (Barc) 1995;104:437.

36 Domingo-Salvany A, Hartnoll RL, Maguire A, et al. Analytical considerations with capture-recapture prevalence estimation: case studies of estimating opiate use in Barcelona Metropolitan Area. Am f Epidemiol 1998;148: 732-40

37 LaPorte RE, Tull ES, McCarty D. Monitoring the incidence of myocardial infarctions: application of capture-recapture technology. Int 7 Epidemiol 1992;21:258-63.

38 Brugal MT, Graugés D, Queralt A, et al. Sistema d'Informació de Drogodependencies de Barcelona. Informe 1993. Barcelona: Institut Municipal de Salut Pública, Ajuntament de Barcelona, 1995.

39 Hay G. The selection from multiple data sources in pidemiological capture-recapture studies. The Statistician 1997; 46:515-20.

40 Domingo A, Antó JM, Camí J. Epidemiological surveillance of opioid-related episodes in an emergency room of Barceona, Spain (1979-1989). British Fournal of Addiction 1991; 86:1459-66.

41 Pompidou Group. Synthesis report. Census and treatment demands in nine European cities. Strasbourg: Council of Europe Press, 1995.

42 Susser M. The logic in ecological: I. The logic of analysis. Am f Public Health 1994;84:825-9.

43 Borrell C, Plasencia A, Pasarin I, et al. Widening social inequalities in mortality the case of a southern European city (Barcelona). I Epidemiol Community Health 1997;51: $659-67$.

44 Putnam RD. The prosperous community. Social capital and public life. The American Prospect 1993; 145:35-42.

5 Sampson RJ, Raudenbush SW, Earls F. Neighborhoods and violent crime: A multilevel study of collective efficacy. Science 1997; 277:918-24.

46 Wallace R, Wallace D, Andrews H. Aids, tuberculosis, violent crime and low birth in eight US metropolitan areas: Public policy, stochastic, resonance and the regional diffusion of inner city markers. Environment and Planning $A$ 1997;29:525-55. 